Protestantismo em Revista é licenciada sob uma Licença Creative Commons.

http://dx.doi.org/10.22351/nepp.v43i2.2859

\title{
A queda do opressor em poesia: análise exegética de Isaías 47.1-11
}

The oppressor's fall in poetry: exegetical analysis of Isaiah 47.1-11

Tiago Abdalla Teixeira Neto*

\begin{abstract}
Resumo
Este artigo tem como propósito realizar uma análise exegética de Isaías 47.1-11, revelando a crítica poética do profeta judeu à dominação e ao abuso de poder do império babilônico junto com o anúncio de sua queda derradeira. Em primeiro lugar, a análise literária examina a estrutura do texto e os aspectos retóricos do discurso do autor de Isaías 47. Em seguida, o contexto histórico esclarece o ambiente sociorreligioso do público ao qual o profeta se dirige, em que um grupo considerável de judeus sentia-se a atraído a seguir os deuses de seus dominadores, em vez de confiar em Yahweh, a divindade da nação. Por fim, a análise do conteúdo investiga a mensagem, de maneira detalhada, proclamada pelo profeta judeu, revelando tanto a crença na soberania universal de Yahweh quanto a faceta transitória do império caldeu autoconfiante.
\end{abstract}

\section{Palavras-chave}

Babilônia. Exílio. Exegese. Isaías 40-55. Profetas.

\begin{abstract}
This article aims to perform an exegetical analysis of Isaiah 47.1-11, revealing the poetic criticism of the Jewish prophet against the domination and power misuse of the Babylonian empire along with the announcement of its final fall. First, the literary analysis examines the structure of the text and rhetorical aspects of author's speech in Isaiah 47. Then the historical context explains the socio-religious environment of the audience to which the prophet addresses, in which a large group of Jews felt drawn to follow the gods of their rulers, instead of relying on Yahweh, the nation's divinity. Finally, the content analysis investigates, in detail, the message proclaimed by the Jewish prophet, revealing both the belief in the universal sovereignty of Yahweh as the transitory aspect of self-confident Chaldean empire.
\end{abstract}

\section{Keywords}

Babylon. Exile. Exegesis. Isaiah 40-55. Prophets.

[Texto recebido em setembro de 2016 e aceito em janeiro de 2018, com base na avaliação cega por pares realizada por pareceristas ad hoc]

* Mestrando em Ciências da Religião (UMESP). Bacharel em Teologia (FTSA). Bolsista da CAPES. E-mail: tatn84@hotmail.com 


\section{Introdução}

Como oferecer esperança a um povo cativo, distante da terra natal e sem expectativa de recomeçar a vida em sua pátria? Em meio a tantos deuses no contexto do império, Yahweh poderia ainda fazer alguma reivindicação? Poderia ele alegar soberania sobre os demais quando seu povo, Judá, encontrava-se cativo?

O autor de Deutero-Isaías ${ }^{1}$ (Is $40-55$ ) buscou lidar com dilemas dos judeus deportados para Babilônia sob vários ângulos. Este artigo tem como propósito interpretar a mensagem de Isaías 47.1-11, examinando aspectos literários e gramaticais, bem como o contexto histórico-social do público-alvo do profeta.

\section{Análise Literária de Isaías 47.1-11}

\section{Contexto Literário, Delimitação e Estrutura de Isaías 47}

O capítulo 47 forma uma unidade literária cujo foco é a queda da cidade de Babilônia, ${ }^{2}$ dando sequência e esclarecendo a razão do exílio de seus deuses retratado no capítulo $46 .^{3}$ A relação lógica com o contexto anterior também ocorre pelo fato de que se as divindade babilônicas foram expostas à vergonha pública e perderam sua legitimidade (Is 46), conclui-se que o poder político ao qual dão sustentação será objeto de zombaria e rejeitado (Is 47$).{ }^{4}$

Da perspectiva do povo judeu oprimido, a relação entre os capítulos 46 e 47 consiste no seguinte quadro: a superioridade do Deus de Israel sobre os deuses do opressor $(46.1-2,3-5,6-7,8-11)^{5}$ dá ensejo para o anúncio de libertação a Sião (46.12-13), que se concretizará na subjugação inevitável de Babilônia (47.1-15).

Além da mudança de foco dos deuses para a capital do império babilônico, que estabelece a distinção entre a unidade do capítulo 46 e a do 47, Severino Croatto observa também um marcador literário importante que reforça a separação. ${ }^{6}$ Enquanto o capítulo 46 alterna entre a descrição na terceira pessoa singular e plural para falar das divindades

1 Neste artigo, utiliza-se a expressão "Deutero-Isaías" em referência à seção literária de Isaías 40-55, sem juízo de valor sobre o autor dessa divisão literária que pertence à obra intitulada "Isaías".

2 OSVALT, John N. The book of Isaiah: chapters 40-66. Grand Rapids: Eerdmans, 1998. p. 240; CHILDS, Brevard S. Isaiah. Louisville: Westminster John Knox, 2001. p. 365; CROATTO, J. Severino. Isaías: la palabra profética y su relectura hermenêutica. Buenos Aires: LUMEN, 1994. p. 159.

3 GOLDINGAY, John. Isaiah. Peabody: Hendrickson, 2001. p. 267; GROGAN, Geoffrey W. Isaiah. In: GAEBELEIN, Frank E. (Org.). The expositor's Bible commentary. Grand Rapids: Zondervan, 1992. v. 6. p. 277.

4 BRUEGGEMANN, Walter. Isaiah 40-66. Louisville: Westminster John Knox, 1998. p. 92.

5 Nessa estrutura, percebe-se, claramente, um arranjo quiasmático de quatro partes, antes da conclusão em 46.12-13, que sustenta a superioridade de Yahweh:

A. Os deuses babilônios são um fardo pesado carregado por animais e seus adoradores exaustos (1-2);

B. O incomparável Deus de Israel é quem tem carregado seu povo desde o nascimento até o futuro (3-5);

$A^{\prime}$. Os deuses babilônios são ídolos imóveis e incapazes de salvar, criados por seres humanos (6-7);

$B^{\prime}$. O Deus singular de Israel planeja sua ação salvadora futura na história e a realiza (8-11).

6 CROATTO, 1994, p. 159. 
babilônicas (v. 1-2, 6-7) e o discurso direto ao Israel rebelde na segunda pessoa do masculino plural (v. 3-5, 8-11, 12-13), o capítulo 47 é dominado por um discurso direto, em que Yahweh se dirige basicamente à Babilônia, com o emprego da segunda pessoa do feminino singular. ${ }^{7}$

Portanto, por razões temáticas e literárias, Isaías 47 deve ser visto como unidade literária completa, distinta do capítulo 46, mas, ao mesmo tempo, relacionada a ele. O final do capítulo 46 (v. 12-13) funciona como uma dobradiça, em que o anúncio de salvação a Sião prepara o leitor para o anúncio de destruição da Babilônia (Is 47). ${ }^{8}$ O obstáculo para a salvação de Israel será removido.

A queda de Babilônia (Is 47) abre caminho para outro discurso, com um novo tema, cujo objeto central é a "casa de Jacó" (Is 48). ${ }^{9}$ Fica evidente o início de uma nova unidade literária, pois o foco já não é mais a "filha de Babilônia", mas a comunidade exilada, que é confrontada por sua desobediência obstinada e idolatria (48.1-11, 12-19) e chamada a fugir de Babilônia, que está fadada à destruição, em um novo Êxodo (48.20-22). “Com os ídolos eliminados (44.24-46.13) e o poder político de Babilônia destruído (cap. 47), agora resta o principal obstáculo para o novo Êxodo: o próprio Israel". ${ }^{10}$ Assim, o capítulo 48 apresenta "a correção divina do apego de Israel à Babilônia, de onde o povo escolhido deve fugir para poder experimentar a libertação e a graciosa provisão divinas" . ${ }^{11}$ Apesar da evidente separação entre a unidade do capítulo 47 e a do capítulo 48, percebe-se um eixo temático que as liga. Diante da eventual queda de Babilônia (47) e do exílio de seus deuses (46), Israel corre sério risco caso continue encantado com os deuses de seu opressor e permaneça em Babilônia. Por isso, Yahweh confronta a nação com a tolice de adorar falsos deuses e os conclama a fugir da capital imperial (48).

Da perspectiva literária, a ruptura é indicada pela mudança do destinatário do discurso, em que os verbos na segunda pessoa do feminino singular em Isaías 47 não são mais usados, e, em vez disso, predominam os verbos na segunda pessoa do masculino alternando entre plural e singular ("casa de Israel” é um singular coletivo) ${ }^{12}$ - em Isaías 48.

Ao analisarmos a estrutura literária de Isaías 47 e do trecho que abrange os versículos 1-11, precisamos ter em mente que a natureza unificada do poema é tão forte

7 FRANKE, Chris A. The function of the satiric lament over Babylon in Second Isaiah (XLVII). Vetus Testamentum, v. 41, n. 4, 1991. p. 411.

8 SMITH, Gary V. Isaiah 40-66. Nashville: Broadman \& Holman, 2009. p. 297; ver também: OSVALT, 1998, p. 240.

9 CROATTO, 1994, p. 159.

10 LACK, R. La symbolique du livre d'Isaïe. Analecta Biblica. Roma: PIB, 1973. p. 106.

11 PINTO, Carlos Osvaldo. Foco e desenvolvimento no Antigo Testamento. São Paulo: Hagnos, 2006. p. 595.

12 Ver o conceito de singular coletivo de substantivos no hebraico em WALTKE, Bruce K.; O'CONNOR, M. Introdução à sintaxe do hebraico bíblico. São Paulo: Cultura Cristã, 2006. p. 112-114. 
que não há acordo entre os estudiosos quanto às divisões exatas do texto. ${ }^{13}$ Brevard Childs afirma que o caráter coeso dessa unidade não é afetado pelo modo como alguém divide o capítulo. ${ }^{14}$ Claus Westermann propõe, com base na forma literária que classifica a profecia, cinco divisões/estrofes: 1-4, 5-7, 8-9, 10-12 e 13-15.15 Severino Croatto identifica uma divisão com duas partes principais, a primeira apresenta uma lamentação por Babilônia (v. 1-7), e a segunda focaliza o discurso profético de anúncio do castigo (v. 8-15). ${ }^{16}$ John Osvalt organiza o capítulo de acordo com os temas que identifica: introdução (v. 1-4), a tolice do orgulho de Babilônia (v. 5-11) e a incapacidade daqueles que supostamente ajudariam Babilônia (12-15). ${ }^{17}$

John Goldingay propõe uma estrutura que nos parece ser mais coerente. A imagem que predomina na profecia de uma mulher poderosa e de requinte que é tirada de sua exaltada posição e passa a desempenhar um papel de escrava sujeita às ordens de alguém superior sugere que o texto seja lido de acordo com os imperativos no hebraico seguidos por discursos que marcam quatro divisões básicas: ${ }^{18}$
A. "Desce e assenta-te no pó" (v. 1-4);
B. "Assenta-te calada e entra nas trevas" (v. 5-7);
C. "Pois bem, ouve isto..." (v. 8-11);
D. "Permanece com tuas palavras mágicas" (v. 12-15).

Além dos imperativos como marcadores literários, cada divisão apresenta um tema unificador que a distingue das demais e justifica a estrutura: ${ }^{19}$
A. Introdução: A humilhação de Babilônia é resultado da vingança de Deus contra ela (v. 1-4);
B. A opressão e o orgulho de Babilônia provocaram a ira de Deus contra o império (v. 5-7);
C. A falsa segurança e a soberba de Babilônia são contrapostas às calamidades que lhe sobrevirão (v. 8-11);
D. Conclusão: Os experts religiosos de Babilônia não poderão salvá-la de sua ruína (v. 12-15).

A elaboração da estrutura de Isaías 47 acima esclarece a delimitação da análise de conteúdo deste artigo das três primeiras divisões do capítulo, iniciando no versículo 1 e finalizando no 11, que conclui a terceira parte.

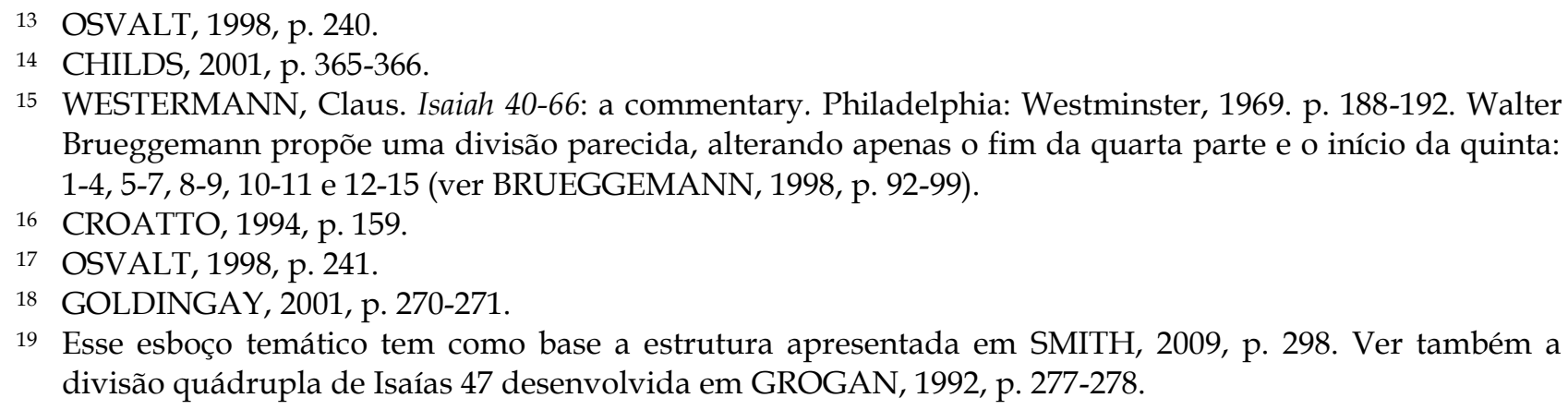
Brueggemann propõe uma divisão parecida, alterando apenas o fim da quarta parte e o início da quinta: 1-4, 5-7, 8-9, 10-11 e 12-15 (ver BRUEGGEMANN, 1998, p. 92-99).

16 CROATTO, 1994, p. 159.

17 OSVALT, 1998, p. 241.

18 GOLDINGAY, 2001, p. 270-271.

19 Esse esboço temático tem como base a estrutura apresentada em SMITH, 2009, p. 298. Ver também a divisão quádrupla de Isaías 47 desenvolvida em GROGAN, 1992, p. 277-278. 


\section{Coesão e Aspectos Retóricos de Isaías 47}

O capítulo 47 como um todo e o trecho em análise aqui (47.1-11) estão repletos de elementos retóricos que realçam de forma irônica a falsa confiança da "filha de Babilônia" e seu humilhante fim, estabelecendo também a coesão da passagem.

A repetição de alguns verbos em especial tem uma função artística e unificadora

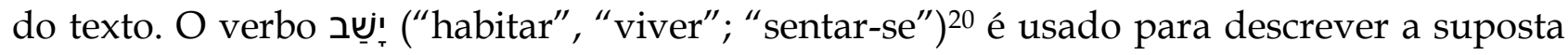

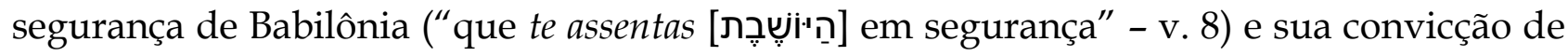
que não sofreria o triste destino da viuvez ("não me assentarei [אֵنֵِב] como viúva" - v. 8). No entanto, os pensamentos de Babilônia se mostram equivocados, pois ela recebe a ordem do "Santo de Israel" para se assentar no pó e na terra ("Desce e assenta-te ['יְִ̣] no pó [...] " - v. 1) e, depois, para se assentar calada ("Assenta-te [نשְ̣] em silêncio..." - v. 5) e entrar nas trevas. ${ }^{21}$ Aqui, há um claro contraste entre o que a Babilônia personificada imagina e o que lhe ocorre de fato.

O verbo בּ ("vir"; "ir"; "entrar")22 retrata a nova condição calamitosa e os desastres que sobrevirão a Babilônia. Primeiramente, ela recebe a ordem para entrar (إخب̣x) nas trevas (v. 5), seu novo status, distinto do anterior de rainha dos reinos. Então, uma série de catástrofes lhe sobrevêm e constituem sua punição: ${ }^{23}$ a viuvez e a perda de filhos

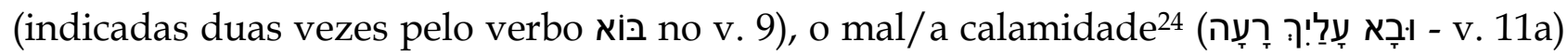

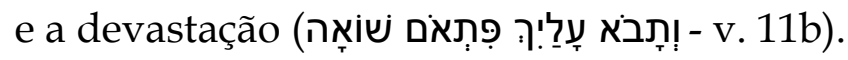

Os dois termos que expressam o campo semântico da inexistência אֵֵ e אִֶ ("não há" $)^{25}$ também funcionam como mais um fio da corda de termos que une as seções em Isaías 47. A rainha soberba pensava que "não há" ninguém além dela (티 - v. 8, 10), gloriosa, poderosa e segura, mas descobrirá que, na realidade, já nãa haverá mais trono

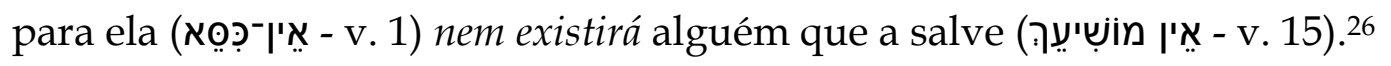

O verbo רָאָה ("ver", "observar")27 reforça a compreensão absolutamente falsa que Babilônia tem de si mesma e de sua condição. Ela pensa que "ninguém está me vendo" ( אִ

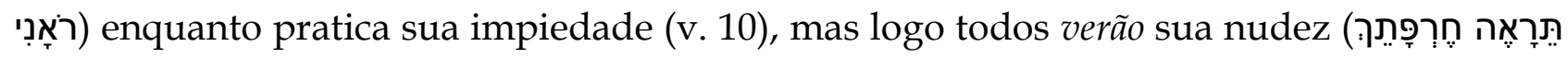
- v. 3) como parte do castigo de Yahweh. ${ }^{28}$

20 BROWN, F.; DRIVER, S.; BRIGGS, C. The Brown-Driver-Briggs Hebrew and English lexicon. Oxford: Clarendon, 1977. p. 443.

21 SMITH, 2009, p. 298.

22 HOLLADAY, W. L.; KÖHLER, L. A concise Hebrew and Aramaic lexicon of the Old Testament. Leiden: Brill, 2000. p. 34-35.

23 FRANKE, 1991, p. 412.

24 ALONSO SCHÖKEL, Luis. Dicionário bíblico hebraico-português. São Paulo: Paulus, 1997. p. 625-626.

25 Ver BROWN; DRIVER; BRIGGS, 1977, p. 67, que indica que os dois termos são sinônimos.

26 SMITH, 2009, p. 298-299.

27 KIRST, Nelson, et al. Dicionário hebraico-português e aramaico-português. São Leopoldo: Sinodal, 1987. p. 220.

28 FRANKE, 1991, p. 413. 
Outras conexões de vocábulos e de temas poderiam ser apontadas, ${ }^{29}$ mas destacaremos, por fim, o tema da "humilhação progressiva" que perpassa o capítulo 47: (a) Babilônia precisa descer de seu trono para se assentar na terra (v. 1), (b) perde seus títulos e seu status de rainha (v. 1, 5), (c) uma série de desastres sobrevêm a ela (v. 9, 11) e (d) seus sábios e religiosos astrólogos são incapazes de ajudá-la e salvá-la de sua futura destruição (v. 12-15). ${ }^{30}$

O capítulo 47 é uma bela obra de arte do autor de Deutero-Isaías, repleta de ironia e de termos e conceitos que costuram sua mensagem, comunicando ao povo exilado que não há motivo para temer seus dominadores, muito menos para ser seduzido pelo poder deles e pelos deuses que, supostamente, os sustentam.

Esse capítulo apresenta um contraste impactante entre o presente de um império bem estabelecido e o futuro iminente que está sob o controle de Yahweh. O império, ao contrário do que parece, é impotente e sem recursos. Os exilados não devem se fixar na aparência ostentosa do império. Tudo precisa ser repensado na presença do "Santo de Israel", diante de quem o império não tem chance alguma. ${ }^{31}$

\section{Forma Literária de Isaías 47}

Dentre as várias formas literárias do discurso profético, ${ }^{32}$ Isaías 47 parece corresponder melhor aos chamados "Oráculos contras as Nações” (e.g., Is 13-23; Jr 46-51; Ez 25-31). ${ }^{33}$ R. N. Whybray observa conexões entre Isaías 47 e outros “Oráculos contras as nações", que também têm hinos fúnebres e sátiras. ${ }^{34}$ Claus Westermann realça dois elementos básicos desse tipo de oráculo: (a) a acusação e sua elaboração e (b) a intervenção de Deus e suas consequências; ambos estão presentes nas duas partes centrais de Isaías 47 (v. 5-7 - acusação e elaboração; v. 9-11 - intervenção de Deus e suas consequências). ${ }^{35}$

Deve-se assinalar também que os oráculos de juízo em geral contêm três aspectos literários que estão presentes em Isaías 47: acusação de desobediência; anúncio da fórmula do mensageiro (e.g., "Assim diz o Senhor") e a predição de juízo. ${ }^{36}$ Como tais elementos não precisam aparecer exatamente nessa ordem, observa-se que o anúncio da fórmula do

29 Ver a lista apresentada em SMITH, 2009, p. 299.

30 FRANKE, 1991, p. 414.

31 BRUEGGEMANN, 1998, p. 100.

32 Para um resumo das várias formas literárias propostas para classificar Isaías 47, ver SMITH, 2009 , p. 298.

33 OSVALT, 1998, p. 241; WESTERMANN, 1969, p. 188-190. Alonso Schökel também entende esse capítulo de Isaías como um oráculo contras as nações. Ele afirma: “No espírito dos oráculos clássicos contra impérios e governantes pagãos, o poeta compõe uma sátira contra Babel (cap. 47)”. ALONSO SCHÖKEL, Luis. Isaías. In: ALTER, Robert; KERMODE, Frank. Guia Literário da Bíblia. São Paulo: Unesp, 1997. p. 191.

34 WHYBRAY apud SMITH, 2009, p. 298.

35 WESTERMANN, 1969, p. 189-190.

36 BYARGEON, Rick. Thus saith the Lord: interpreting the prophetic word. In: CORLEY, Bruce; LEMKE, Steve W.; LOVEJOY, Grant I. Biblical hermeneutics: a comprehensive introduction to interpreting Scripture. 2. ed. Nashvile: Broadman \& Holman, 2002. p. 302-303. 
mensageiro aparece na introdução da profecia (v. 1-4), ${ }^{37}$ seguido pela acusação de desobediência (v. 5-7) e a predição do juízo inescapável (9-11, 12-15). Portanto, o conteúdo do trecho de Isaías em análise será abordado como um oráculo contra Babilônia à semelhança dos que ocorrem em Isaías 13 e $14 .{ }^{38}$

\section{O contexto sociopolítico e religioso de Isaías 47.1-11}

Embora alguns estudiosos tenham proposto um ambiente pós-exílico para Isaías 40-55,39 a grande maioria da academia defende um público do Exílio, no máximo, no período imediatamente posterior em que Ciro conquista Babilônia. ${ }^{40}$ Portanto, a análise a seguir trata de um contexto sociopolítico e religioso em que os babilônios dominavam o cenário mundial, embora os persas assumiriam depois essa posição de supremacia política no Antigo Oriente Próximo. ${ }^{41}$

\section{Deuses, reis e nações}

Diante da derrota de Judá para os babilônios, com uma parte do povo exilado em terra estrangeira e a destruição final de Jerusalém por Nabucodonosor, um questionamento natural, certamente, brotaria no coração dos judeus: "será que Yahweh é, de fato, o Rei e Deus Soberano da história? Acaso teria ele poder para vencer impérios e

37 Quanto à fórmula desse anúncio, ver a "Análise do Conteúdo" deste artigo.

38 SMITH, 2009, p. 297-298.

39 Entre os estudiosos que defendem um Sitz im Leben pós-exílico está Rainer Albertz. Veja seu artigo: ALBERTZ, Rainer. Darius in place of Cyrus: the first edition of Deutero-Isaiah (Isaiah 40.1-52.12) in 521 BCE. Journal for the Study of the Old Testament, v. 27, n. 3, 2003. p. 371-383.

40 Ver, e.g., PLEINS, J. David. The social visions of the Hebrew Bible: a theological introduction. Louisville: Westminster John Knox, 2001. p. 264-265; GOLDINGAY, 2001, p. 4, 30; WESTERMANN, 1969, p. 3-6; WESTERMANN, Claus. Handbook to the Old Testament. Minneapolis: Augsburg, 1967. p. 144.

41 Observe-se que a ênfase deste parágrafo está no "público" / nos "destinatários" / na "audiência" de Isaías, sem uma discussão mais delongada sobre a autoria isaiânica. Definir se a profecia é, por natureza, preditiva ou se é um vaticinium ex eventu são ambas posições de fé. Uma envolve a crença na revelação sobrenatural divina, a outra implica crer na impossibilidade da interferência sobrenatural do divino na história dos homens de uma forma que "viole" os princípios da suposta "lei da natureza". Em resposta à acusação de crer em clarividência, feita por Brevard Childs, John Osvalt - autor do comentário de Isaías da respeitada série New International Commentary on the Old Testament - respondeu: "Childs é bem claro nesse aspecto, afirmando que os autores exílicos e pós-exílicos teriam, originalmente, incluído outros detalhes históricos específicos, conforme a tradição da literatura bíblica, e esses detalhes foram apagados para dar a ideia de que o texto foi obra de um profeta mais antigo. No entanto, não faria mais sentido reconhecer que esses detalhes não foram incluídos porque o profeta mais antigo não os conhecia, conforme o livro parece se empenhar em afirmar? [...] grande parte do argumento em favor da superioridade de Yahweh sobre os deuses de Babilônia presente nos capítulos 40-55 é elaborado para sustentar a capacidade de Yahweh de predizer o futuro, isto é, que Israel iria para o cativeiro e seria liberto do cativeiro por um homem chamado Ciro. Se essas predições foram obra do assim chamado Deutero-Isaías ao escrever por volta de 545 a.C., depois de Ciro ter começado a realizar invasões significativas no território babilônico, e se esse profeta anônimo precisou colocá-las na boca de alguém que supostamente as pronunciou 150 anos antes para que tivessem validade, o que sucederia com o argumento, sem falar na integridade dessa pessoa anônima chamada de o maior teólogo de Israel?" (OSVALT, John N. The holy one of Israel: studies in the book of Isaiah. Eugene: Cascade, 2014. p. 74). 
trazer seu povo de volta à terra natal?". ${ }^{42}$ No pensamento do Antigo Oriente Próximo, a vitória de uma nação sobre outra não apenas implicava supremacia militar, mas também, indicava a superioridade do deus vitorioso sobre a divindade do povo vencido. ${ }^{43}$

A riqueza do império babilônio, seus belos templos e festivais pomposos, além do conforto que a comunidade judaica de exilados desfrutava, certamente formavam um quadro tentador para a apostasia judaica. ${ }^{44} \mathrm{O}$ profeta direciona sua mensagem a esses exilados na Babilônia, que viviam longe de sua terra (40.1-2; 42.22, 24; 48.20; 50.1-2), após a destruição de Jerusalém e do Templo $(44.26-28 ; 51.3 ; 52.9)$ e sem esperança de retorno a Judá (40.27-28).

Nessa situação, a mensagem visionária de Isaías 40-55 oferecia uma resposta teológica profunda e pertinente a seu povo, mostrando Yahweh como o soberano da história, o Deus supremo e singular. ${ }^{45}$ "No final, Yahweh não seria vencido por Marduque, deus dos babilônios. A razão era muito simples: não há outro deus além de Yahweh. O monoteísmo foi afirmado com insistência pelo autor de Deutero-Isaías: 'Eu e somente eu sou o Senhor, além de mim não há salvador' (Is 43.11)" ${ }^{46}$

\section{O cativeiro dos Judeus}

Após as deportações de judeus para a Babilônia, os pobres e miseráveis permaneceram na terra (2Rs 24.14-15; 25.1-12; Jr 39.9-10), enquanto a elite da sociedade hebraica encontrava-se exilada na capital do império de sua época.

Apesar de tentativas de negar o Exílio, os textos bíblicos e as evidências arqueológicas demandam esse fato. Em uma análise demográfica de Judá e Benjamim que compara a população do fim da Idade do Ferro e a do início do Período Persa, com base em dados arqueológicos, Lipschits mostra que houve um decréscimo de quase $70 \%$ do número de habitantes: "[...] parece que a destruição de Jerusalém e o final do reino de Judá levaram à mais grave crise demográfica na história do reino de Judá - bem mais severa que aquela produzida pela campanha de Senaqueribe (701 AEC)" ${ }^{47}$

42 Cf. BRIGHT, John. História de Israel. 7. ed. São Paulo: Paulus, 2003. p. 425; CALVIN, John. Commentary on the prophet Isaiah. Albany: AGES, 1998. v. 2. p. 71.

43 Mark Smith observa: "a teologia mundial foi uma premissa para a correlação de reis divinos e humanos: enquanto os reis humanos estavam no poder, ele era um sinal do poder e de proteção divinos. Pelo padrões do antigo Oriente Próximo, entretanto, a derrota de uma nação poderia também indicar a impotência de seu deus patrono. Quando o reino do norte (Israel) caiu, pode ter parecido que o deu patrono do norte podia ser correspondentemente fraco" (SMITH, Mark. O memorial de Deus: história, memória e a experiência do divino no Antigo Israel. São Paulo: Paulus, 2006. p. 174).

44 BRIGHT, 2003, p. 417.

45 Cf. VON RAD, Gerhard. Teologia do Antigo Testamento. 2. ed. São Paulo: ASTE, 2006. p. 663-665.

46 VITÓRIO, Jaldemir. Proclamar la esperanza en medio del fracaso: teologia bíblica del exílio. Christus, v. 69, n. 747, 2005. p. 16.

47 LIPSCHITS, Oded. Demographic changes in Judah between the seventh and the fifth centuries BCE. In: LIPSCHITS, Oded; BLENKINSOPP, Joseph. Judah and the Judeans in the Neo-Babylonian period. Winona Lake: Eisenbrauns, 2003. p. 364. Em uma nota de rodapé na mesma página, Lipschits conclui: “esses 
Tanto a literatura bíblica quanto os dados arqueológicos mostram que os judeus gozaram de certa liberdade e vida relativamente confortável no cativeiro. ${ }^{48}$ Embora não fossem totalmente livres, tinham autonomia para construir suas casas, dedicar-se à agricultura (Jr 29.5ss) ${ }^{49}$ e ao comércio.50 “A integração dos judeus à vida econômica babilônica é comprovada pela participação deles em transações econômicas do dia a dia em que são registrados tanto como credores quanto como devedores em vários documentos de empréstimos e de recibos". ${ }^{51}$

Alguns judeus parecem ter sofrido bastante com seu novo contexto (cf. S1 79; 137; Is 40.27). Para eles a vida de acordo com a Lei divina só poderia ser vivida na Terra Prometida, sob o cuidado de Deus, com o Templo e o culto restaurados. ${ }^{52}$ Ao mesmo tempo, outros estavam confortáveis em sua condição, haviam se estabelecido na nova terra, desenvolvido sua profissão ali, casado-se com mulheres estrangeiras (cf. Ed 10.10ss.) e provavelmente até adoravam as divindades babilônicas. ${ }^{53}$

\section{O contexto religioso de Isaías 40-55}

A religião babilônica era politeísta, formada por um panteão de vários deuses de origem suméria, assimilados pelos semitas que ali vieram habitar depois da Primeira Dinastia Babilônica (c. século XVIII a.C.). ${ }^{54}$ Os deuses estavam ligados a objetos ou fenômenos da natureza, como os rios, a tempestade, a fertilidade da terra, entre outros, dentre os quais recebiam proeminência o sol e a lua. Portanto, o sistema de crenças era, basicamente, animista. ${ }^{55}$ Cada cidade-Estado possuía um deus patrono principal, e, às

dados não deixam espaço algum para as várias teorias de 'o mito da terra vazia' e ainda confirmam, de modo inequívoco, que a destruição e o exílio foram, de fato, eventos históricos, descritos em sua plena crueldade pela historiografia bíblica e também refletidos nas lamentações e nas profecias desse período". Bob Becking apresenta o mesmo entendimento ao afirmar: "com a ideia de exílio eu me refiro a um movimento em Judá do sexto século AEC. Não se pode negar de modo sério que no início daquele século os habitantes de Jerusalém e de sua vizinhança foram deportados contra sua vontade para a Babilônia. [...] Evidência para essa deportação pode ser encontrada fora do discurso bíblico. [...] Com base no que pode ser comparado, não é possível, de forma séria, negar que, próximo ao final do sexto século AEC, pessoas que estavam em Babilônia começaram a se mudar pra uma área sob a administração persa chamada Yehud" (BECKING, Bob. Ezra's re-enactment of the exile. In: GRABBE, Lester L. (Org.). Leading captivity captive: 'the exile' as history and ideology. Sheffield: Sheffield Academic, 1998. p. 42).

48 VEEN, Peter van der. Sixth-century issues: the fall of Jerusalem, the Exile and the return. In: HESS, Richard S.; ARNOLD, Bill T. (Orgs.). Ancient Israel's history: an introduction to issues and sources. Grand Rapids: Baker, 2014. p. 401-402.

49 BRIGHT, 2003, p. 467.

50 MERRILL, Eugene H. História de Israel no Antigo Testamento. Rio de Janeiro: CPAD, 2001. p. 511.

51 PEARCE, Laurie. New evidence for Judeans in Babylonia. In: LIPSCHITS, Oded; OEMING, Manfred (Orgs.). Judah and the Judeans in the Persian Period. Winona Lake: Eisenbrauns, 2006. p. 402.

52 VEEN, 2014, p. 401.

53 MYERS, A. C. (Org.). The Eerdmans Bible dictionary. Grand Rapids: Eerdmans, 1987. p. 362.

54 WISEMAN, D. J. Babylonia. In: MARSHALL, I. H. et al. (Orgs.). New Bible dictionary. 3. ed. Downers Grove: InterVarsity, 1996. p. 115-116.

55 ROGERS, Robert W. Babylonia and Assyria, religion of. In: ORR, James (Org.). The international Standard Bible encyclopedia. Grand Rapids: Eerdmans, 1939. Edição eletrônica. 
vezes, uma divindade de importância primária em um determinado centro urbano poderia ser considerada secundária em outra cidade. ${ }^{56}$

A grande corrente de ideias religiosas sofreu mudanças de tempos em tempos e os próprios deuses mudaram de locais, identidade e funções, conforme os movimentos políticos e outras transformações. ${ }^{57}$ Com a supremacia dos amorreus, a adoração a Marduque se tornou a principal na Babilônia ${ }^{58}$ e o poema épico de Enuma Elish foi desenvolvido a fim de validar a posição de Marduque como o maior de todos os deuses, por sua vitória sobre a deusa Tiamat e por ser tanto o criador como o restaurador da ordem do universo. ${ }^{59}$

Tendo esta compreensão acerca da ênfase astral da religiosidade babilônica e do importante papel que Marduque ocupava na cosmologia mitológica, abre-se o caminho para a interpretação de Isaías 47 , um texto que anuncia a derrocada do império babilônico pressupondo também a derrota de seus deuses (Is 46).

Quando os deuses babilônicos são expostos e deslegitimados em 46.1-2, 5-7, a conclusão imediata e inevitável é a de que o poder político babilônico logo será ridicularizado e desprezado no capítulo 47; o único propósito dos deuses é conferir fundamento ideológico e legitimidade ao poder humano. ${ }^{60}$

\section{Análise do conteúdo de Isaías 47.1-11}

A seguir, desenvolvemos a análise do conteúdo de Isaías 47.1-11, expondo a mensagem comunicada pelo antigo profeta por meio do exame de aspectos sintáticos, semânticos e literários de cada versículo de acordo com a estrutura proposta na Análise Literária.

Desce e assenta-te no pó (47.1-4)

O versículo inicial do trecho em análise começa com dois imperativos à capital de um poderoso império. $O$ autor emprega a personificação, tratando o grupo representado pela cidade de Babilônia - todos os que desfrutavam dos benefícios alcançados pelo império à custa dos povos dominados - como se fosse uma pessoa. ${ }^{61}$ Acostumada a exercer o domínio, a "senhorita Babilônia" agora recebe uma ordem e precisa enfrentar a dura realidade. "Embora Babilônia se considerasse destinada a um trono, seu lugar por

\footnotetext{
56 MACKENZIE, Donald A. Myths of Babylonia and Assyria. London: The Gresham, 1915. p. 40.

ROGERS, 1939.

58 WISEMAN, 1996, p. 116.

59 LEICK, Gwendolyn. A dictionary of Ancient Near Eastern Mythology. New York: Routledge, 2003. p. 52-55.

60 BRUEGGEMANN, 1998, p. 92.

61 Ryken faz uma observação hermenêutica importante: "por fim, a presença da personificação requer que o leitor perceba que a verdade é comunicada por declarações que não são verdades factuais. Sempre que o poeta personifica algo, ele está brincando de jogo de faz de conta". RYKEN, Leland. Words of delight: a literary introduction to the Bible. Grand Rapids: Baker, 1992. p. 178.
} 
direito é o pó". 62 Há um soberano, da perspectiva do profeta judeu (cf. comentário do v. 4), que de fato exerce poder universal, inclusive sobre o grande poder até aquele momento, o Império Babilônico. ${ }^{63}$

A nova posição subalterna de Babilônia fica bem clara com os imperativos que dominam a passagem. A "senhora de reinos" não decide mais o que fazer, apenas executa as ordens que recebe de alguém superior. "Para a comunidade judaica esse poema é tanto uma promessa de que seu opressor será derrubado quanto uma advertência para não leválo muito a sério". 64

Os verbos hebraicos ירְִִ ("desce") e ("denta-te”) retratam o movimento de alguém que está assentada em trono exaltado, em uma pomposa corte, e, então, sai dessa condição e desce para assentar-se no pó (v. 1). ${ }^{65} \mathrm{O}$ vocábulo ("pó") é uma expressão figurativa para uma condição de humilhação, fragilidade ou insignificância (cf. Gn 18.27; Sl 103.14), 66 indicando tanto lamento quanto destruição no livro de Isaías (Is 3.26; 25.12; 26.5). ${ }^{67}$

As construções "virgem, filha de Babilônia" e "filha dos caldeus" (v. 1) são títulos de honra, cujo foco não está na idade jovem de Babilônia, mas na figura da moça virgem como bela, desejável e inconquistável. ${ }^{68}$ A expressão não é nova, pois foi utilizada em outros textos, alterando apenas o nome da cidade, região ou nação (Sião, Is 37.22; Egito, Jr 46.11; Israel, Am 5.2). ${ }^{69}$

Babilônia estava acostumada a ser uma cidade elegante, extravagante, atraente e impressionante, descrita com a linguagem retórica da feminilidade. No entanto, tal declaração sobre o passado serve apenas para realçar o presente, em que essa beleza anterior se transformará, agora, em uma escrava abandonada, vulnerável e explorada, sem qualquer proteção do cenário social, em completo risco e humilhada. ${ }^{70}$

62 OSVALT, 1998, p. 241.

63 CHISHOLM JR., Robert B. Uma teologia de Isaías. In: ZUCK, Roy B. Teologia do Antigo Testamento. Rio de Janeiro: CPAD, 2009. p. 368.

64 GOLDINGAY, 2001, p. 270.

65 CROATTO, 1994, p. 161; SMITH, 2009, p. 300.

66 GESENIUS, F. W. Gesenius' Hebrew and Chaldee lexicon to the Old Testament Scriptures. Bellingham: Logos Bible Software, 2003. p. 645; BROWN; DRIVER; BRIGGS, 1977, p. 780. Wanke destaca a relação do termo com a humilhação, o abatimento e a insignificância como um estado causado ou extinto por Yahweh, seja no abatimento e destruição de cidades ("lança ao pó", Is 25.12 e 26.5) ou na remoção da degradação e da insignificância experimentadas por uma pessoa ("ergue do pó", 1 Sm 2.8; 1 Rs 16.2). Ver WANKE, G. עָ. In: JENNI, Ernst; WESTERMANN, Claus (Orgs.). Theological lexicon of the Old Testament. Peabody: Hendrickson, 1997. v. 2. p. 940.

67 SMITH, 2009, p. 300.

68 SMITH, 2009, p. 300.

69 CROATTO, 1994, p. 162.

70 BRUEGGEMANN, 1998, p. 93. 
A razão para esse movimento de exaltação - humilhação ou de glória - abatimento

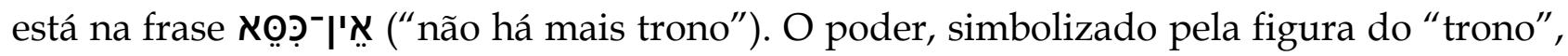
que Babilônia exerceu e desfrutou durante décadas já não existe mais. Agora, cabe a ela aceitar seu destino, em que não será mais chamada de “delicada" e "mimada" (v. 1): “os termos trazem à memória a ideia de luxo, requintes da corte, a vida distinta de divertimento livre de preocupações" ${ }^{71}$

No versículo 2, o trabalho que Yahweh encarrega Babilônia é o de "moer a farinha", uma tarefa servil e cansativa própria das mulheres escravas (cf. Exx 16.21; Lm 5.13; Jó 31.10). ${ }^{72}$ As "duas pedras de moinho" eram, provavelmente, um pequeno conjunto de pedras de moer que seriam utilizados na cozinha, ${ }^{73}$ utensílios domésticos comuns operados por criadas. ${ }^{74}$ Acostumada à ter suas refeições preparadas e servidas por seus criados, agora a rainha que dominava os povos terá ela mesma de realizar essa tarefa.

Outra imagem ocorre no mesmo versículo, confirmando que a "senhora dos reinos" passa a ser uma escrava, na verdade, uma cativa de guerra. O aparato e a etiqueta que caracterizava a alta sociedade da época são abandonados, indicando sua nova condição. ${ }^{75}$ Ela precisa remover seu véu, recolher a borda da saia e atravessar o rio rumo ao exílio (v. 2).

No versículo 3, há uma mudança significativa no aspecto verbal. Em vez dos imperativos predominantes nas construções dos versículos 1 e 2, há apenas verbos no tempo imperfeito. Na primeira metade do trecho, os verbos estão no grau nifal (passivo) para enfatizar que Babilônia não terá mais controle sobre o que lhe sobrevirá, bem como para expressar a violência exterior que sofrerá. ${ }^{76}$

Da mesma forma que Babilônia usou de seus encantos para seduzir outras nações (cf. v. 5-8), Deus mostrará as "partes íntimas" dela perante todos em ato humilhante (v. 3), assim como se fazia com as prostitutas no Antigo Oriente Próximo, levantando seu vestido até cobrir a cabeça e seu corpo ficar completamente exposto ao público (Jr 13.26-27; Ez 16.37-38). ${ }^{77} \mathrm{~A}$ expressão também pode estar relacionada à cena do estupro por soldados

71 WESTERMANN, 1969, p. 190.

72 RIDDERBOS, J. Isaías: introdução e comentário. 2. ed. São Paulo: Vida Nova, 1995. p. 384; CROATTO, 1994, p. 162;

73 SMITH, 2009, p. 301.

74 BROWN; DRIVER; BRIGGS, 1977, p. 932.

75 WESTERMANN, 1969, p. 190; SMITH, 2009, p. 301.

76 CROATTO, 1994, p. 162.

77 JOHNSTON, Gordon H. Nahum's rethorical allusions to neo-Assyrian treaty curses. Bibliotheca Sacra, v. 158, 2001a. p. 427. Johnston declara: "esse tema é utilizado como uma maldição em tratados de Aram e da Assíria dos séculos VIII e VII a.C. Por exemplo, em um tratado arameu de Sefire, Bar-Ga'ayah adverte: 'como uma prostituta é despida, assim também as esposas de Mati'ilu serão despidas, bem como as esposas de seus descendentes e de seus nobres' (Sefire IA, 40-41). [...] Esarhaddon advertiu seus vassalos que se eles se revoltassem, o imperador os trataria como prostitutas: 'que eles os tratem como prostitutas como uma mulher na presença de seu inimigo'." 
vencedores na guerra, uma ação que fazia parte da destruição do inimigo,78 ideia corroborada pela frase inicial do versículo, "as tuas partes íntimas serão reveladas", que pode ser um eufemismo hebraico para "relações sexuais" (cf. Lv 18.6-19). ${ }^{79}$

Quem é o soberano que destrói Babilônia e traz todo esse mal sobre a capital do império? "Eu me vingarei" (v. 3) é uma frase pronunciada por "Yahweh dos Exércitos" que se apresenta logo a seguir. 80 "O agente da destruição é ninguém menos que Yahweh, aquele que se recusou a continuar protegendo Jerusalém em sua obstinação. O Deus que entregou a amada Jerusalém ao sofrimento é o mesmo que aniquilará Babilônia". ${ }^{81}$ Claus Westermann chama atenção para essa apresentação climática nos versículos 3 e 4:

Para termos alguma ideia da audácia do que é afirmado aqui, precisamos compreender exatamente quão fantástica é a sequência dos v. 3ss. logo depois das ordens para que Babilônia seja humilhada - o Deus [supostamente] vencido de uma nação pequena e derrotada se vinga da poderosa e grandiosa Babilônia! A audácia do profeta é resultante do que Deus significa para ele $[\ldots]^{82}$

Como Gary Smith observa, a vingança divina expressa pelo substantivo נָָָ (v. 3) não deve ser vista como "uma retaliação irracional, punitiva e violenta que, em geral, é uma reação desproporcional devido a uma ira incontrolável", mas como "o estabelecimento da justiça contra alguém que praticou um malfeito". 83 A raiz נקם ocorre 79 vezes na Bíblia Hebraica e sua nuance original era, provavelmente, legal. ${ }^{84}$ Alonso Schökel apresenta como traduções possíveis do substantivo נָקָ: "vingança, desforra, revanche, vindícia; satisfação, represália, reparação". 85

78 SMITH, 2009, p. 301-302.

79 SWANSON, J. Dictionary of biblical languages with semantic domains: Hebrew. Oak Harbor: Logos Research Systems, 1997. verbete עִרְרוֹ (Edição Eletrônica); BROWN; DRIVER; BRIGGS, 1977, p. 789.

80 Winton Thomas, editor de Isaías da BHS, indica que a Septuaginta (LXX), acompanhada por Vetus Latina, Siro-Héxapla, Versão Árabe e Versão Etíope, insere ع̃̂nعv antes do termo grego correspondente a

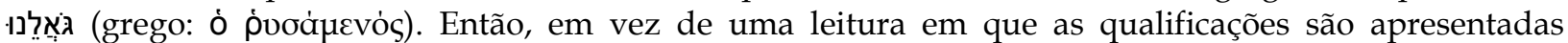
imediatamente ("o nosso Redentor, Yahweh dos Exércitos é seu nome”), o texto da LXX contém o verbo dizer, remetendo o discurso anterior (v. 1-3) ao próprio Yahweh: "disse o Redentor, Yahweh dos Exércitos é seu nome...", ou seja, de acordo com a leitura da LXX, deveria haver o verbo ("falar",

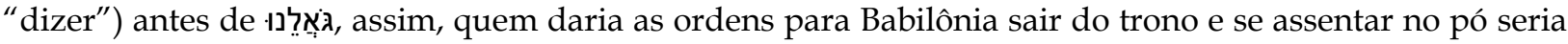
o Deus de Israel. Tal emenda no TM faz sentido e pode ser explicada como um caso de leitura errônea de letras e de haplografia, em que o verbo אָמֵ ("falar", "dizer") foi omitido pelo copista por sua semelhança com a palavra imediatamente anterior, o termo אָָָ אָד

81 BRUEGGEMANN, 1998, p. 94.

82 WESTERMANN, 1969, p. 190-191.

83 SMITH, 2009, p. 302.

84 SAUER, G. "נקטם". In: JENNI, Ernst; WESTERMANN, Claus (Orgs.). Theological lexicon of the Old Testament. Peabody: Hendrickson, 1997. v. 2. p. 767.

85 ALONSO SCHÖKEL, 1997, p. 449. 
Quando considerada uma reação divina contra o pecado dos seres humanos, a vingança é vista na Bíblia Hebraica como um efeito da santidade e justiça de Yahweh. ${ }^{86} \mathrm{~A}$ "vingança" (נָָָם) divina implica manutenção do juízo divino (Dt 32.41), salvação daqueles cujo coração está desalentado (Is 35.4), aplicação da justiça e salvação em retribuição à maldade contra Judá (Is 59.17,18) e consolo dos que choram (Is 61.2). Assim, os indivíduos oprimidos rogam, com frequência, pela vingança divina (Jr 11.20; 15.15; 20.12; Sl 79.10), em vez de tentar executar justiça com as próprias mãos (1Sm 24.13). ${ }^{87}$

Apesar de vingar-se contra os babilônios, os títulos que Yahweh recebe no versículo 4 tinham profunda relação com o aspecto positivo de sua ação: a redenção de seu povo escolhido. Ele é chamado de "Nosso Resgatador", "Yahweh dos Exércitos”, "O Santo de Israel".

Quando Deus é chamado de "Nosso Redentor", o autor de Deutero-Isaías busca restaurar a confiança do povo na proteção divina em meio ao cativeiro. O גִאֵל ("redentor", "resgatador") é um termo bastante recorrente em Isaías e está relacionado aos domínios semânticos da salvação e libertação. Essa metáfora originada do mundo jurídico do antigo Israel era uma referência a um parente próximo responsável por agir em favor de um familiar em risco de perda de propriedade ou de escravidão. $O$ parente-resgatador saldaria a dívida do indivíduo para preservar a herança ou a liberdade dele (Lv 25.47-49; Rt $3.13 ; 4.1-10) .88$

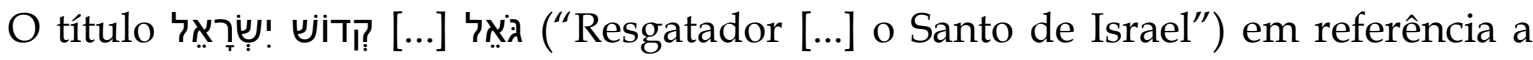
Yahweh ocorre apenas em Isaías em toda a Bíblia Hebraica, e o profeta o emprega seis vezes (Is $41.14 ; 43.14 ; 47.4 ; 48.17 ; 49.7 ; 54.5)$.

Ao estabelecer uma combinação entre os dois termos, o autor indica um paradoxo em que Yahweh, o Separado, pertence a Israel. "Redentor, o Santo de Israel" como um título divino único sugere uma qualificação do relacionamento entre o Redentor Divino e Israel com diferentes significados de posse: 1) Israel é a propriedade de Goel, Qadosh Yisrael; 2) Goel, Qadosh Yisrael é o governante de Israel; 3) Israel é dependente de Goel, Qadosh Yisrael. [...] O Santo Redentor mantém o domínio de seu povo pactual como sua propriedade, o qual talvez seja um reflexo de sua soberania e uma característica de sua alteridade divina. ${ }^{89}$

Yahweh também é chamado de "Yahweh dos Exércitos". Muitos estudiosos vêm observando o uso abrangente do termo צָבָ tanto em relação ao exército humano de Israel

86 SMICK, Elmer B. נקם. In: HARRIS, Laird R.; ARCHER JR., Gleason L.; WALTKE, Bruce K. Dicionário internacional de teologia do Antigo Testamento. São Paulo: Vida Nova, 1998. p. 999-1000.

87 SAUER, 1997, p. 768-769.

88 LONGMAN III, Tremper; DILLARD, Raymond B. Introdução ao Antigo Testamento. São Paulo: Vida Nova, 2006. p. 265.

89 ASHDOWN, Shelley. A cognitive semantic approach to Redeemer (Go7e1) in Deutero-Isaiah. Acta Theologica. v. 35, n. 1, 2015. p. 13. 
(1 Sm 17.45) como, também, em conexão aos seres angelicais (Js 5.14ss) e aos corpos celestes (Dt 4.19; Is 40.26). ${ }^{90}$

O contexto em que esse nome divino é aplicado parece ressaltar não tanto o caráter guerreiro do Deus de Israel, como mais um entre os principais deuses-guerreiros das outras nações,"11 mas, principalmente, o "majestoso esplendor do domínio de Yahweh" $.92 \mathrm{O}$ termo, portanto, é "predominantemente real". 93

Em Isaías, "Yahweh dos Exércitos" está assentado "em um alto e sublime trono" (6.1-3) como um "Rei" (6.5) digno do temor da nação (8.13). No eschaton, ele oferecerá um banquete a todos os povos que estarão sob seu domínio (25.6-7), ${ }^{94}$ pois todos os reinos da terra lhe pertencem e são governados por ele de um trono entre os querubins (Is 37.16).

Ao mesmo tempo, "Yahweh dos Exércitos" é senhor sobre os astros celestiais. Ele mantém, de modo soberano e com poder, a ordem do universo, de modo que nenhuma das inumeráveis estrelas deixa de se submeter ao seu comando (Is 40.26). Todos os corpos celestiais (representantes das divindades babilônicas), inclusive o próprio planeta Júpiter (representante de Marduque), estavam debaixo da autoridade e controle do Deus de Israel. ${ }^{95}$ Portanto, em Isaías 47.4, “o acréscimo de 'Yahweh dos exércitos' é proposital; ele [o profeta] estava pensando na importância atribuída aos corpos celestiais na Babilônia (v. 13); entretanto, não passam de criaturas de Deus [...]". 96

Naturalmente, há uma polêmica em Isaías 47.4: o título nos apresenta quem se assenta, de fato, sobre o trono. Não é Babilônia, mas Yahweh, que a faz assentar-se no pó, ser levada para o exílio e exposta à vergonha pública.

Outro título do versículo 4 é "O Santo de Israel". Na Bíblia Hebraica, o termo קָiim ("santo") é quase um sinônimo da divindade (cp. Am 4.2 com 6.8; cf. Hc 3.3) e indica um mysterium tremendum, lembrando que Deus está acima de todas as fraquezas e imperfeições dos seres humanos, por isso, é capaz de realizar maravilhas (Êxx 15.11). ${ }^{97}$

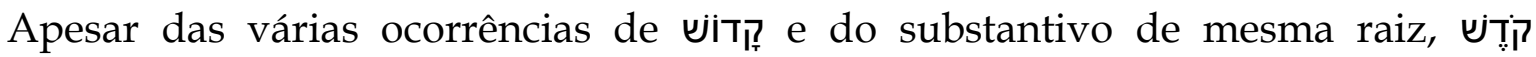
("santidade", "objeto santo"), indicarem a pureza moral de Yahweh ou de seu povo (Lv

90 GORDON, Robert P. 1 \& 2 Samuel: a commentary. Grand Rapids: Zondervan, 1988. p. 72-73; MACK, Eduard. God, names of. In: ORR, James (Org.). The international Standard Bible encyclopedia. Grand Rapids: Eerdmans, 1939. Edição eletrônica; BALDWIN, Joyce G. 1 e 2 Samuel: introdução e comentário. São Paulo: Vida Nova, 1996. p. 57; KEIL, C. F.; DELITZSCH, F. Biblical commentary on the books of Samuel. Edinburgh: T \& T Clark, 1880. p. 19-21.

91 HARTLEY, John E. צִבָא. In: HARRIS, Laird R.; ARCHER JR., Gleason L.; WALTKE, Bruce K. Dicionário internacional de teologia do Antigo Testamento. São Paulo: Vida Nova, 1998. p. 1258-1259.

92 HARTLEY, 1998, p. 1259.

93 ROSS, J. P. Jahweh șebāôt in Samuel and Psalms. Vetus Testamentum, v. 17, n. 1, 1967. p. 78.

94 SMITH, Gary V. Isaiah 1-39. Nashville: Broadman \& Holman, 2007. p. 432-433.

95 GOLDINGAY, 2001, p. 227-228; CALVIN, 1998, v. 2, p. 72-73.

96 WESTERMANN, 1969, p. 191.

97 MCCOMISKEY, Thomas E. קָדָe. In: HARRIS, Laird R.; ARCHER JR., Gleason L.; WALTKE, Bruce K. Dicionário internacional de teologia do Antigo Testamento. São Paulo: Vida Nova, 1998. p. 1322. 
19.2; Js 24.19; Sl 15.1ss; Is 17.7; 30.11, passim), a natureza transcendente e majestosa de Deus parece ser o significado primário de sua santidade. ${ }^{98}$ Em Isaías 6.1-5, que narra o encontro do profeta com o Deus Santíssimo (v. 3), o que predomina na cena é a visão da realeza gloriosa divina e seu poder transcendente (vv. 1-4). ${ }^{99}$

A transcendência divina intrínseca ao conceito de santidade pode ser vista na declaração: "Eu sou Deus e não homem, o Santo no meio de ti" (Os 11.9). Marduque, o grande deus de Babilônia, tinha sua correspondência com o planeta Júpiter ${ }^{100}$ e era representado pela figura mitológica de um ser com longos membros e quatro cabeças. ${ }^{101}$ De modo distinto, Yahweh, por ser o "Santo de Israel", não pode ser igualado a nenhum ser criado, ele é o "totalmente outro".

Assenta-te calada e entra nas trevas (47.5-7)

Uma nova ordem dupla no versículo 5 marca o início de outra divisão em Isaías 47. ${ }^{102}$ Antes, Babilônia deveria descer e se assentar, agora o movimento continua, e ela deve se assentar e entrar nas trevas. A glória, o brilho e o barulho do movimento de seu domínio mundial são substituídos por "trevas" e "silêncio" (v. 5). ${ }^{103}$

"O silêncio é uma imagem bastante eloquente quando se fala de uma capital de império, com suas transações comerciais, seu movimento político, suas festas e os trabalhadores que vão e vem" ${ }^{104}$ A figura do silêncio também pode remeter à palavra imperial que determinava aos vassalos o que deveriam fazer, indicando que Babilônia não mais dirá aos outros povos o que fazer. ${ }^{105}$

As "trevas" também representam o cativeiro em outra passagem de Isaías (42.6-7). Ali, os que "habitam nas trevas" são os próprios “cativos" de Israel, portanto, há uma inversão ${ }^{106}$ em que o dominador experimenta a triste sina daqueles a quem oprime (cf. também Lm 3.2,6).

A "senhora de reinos" (v. 5) é uma lembrança de que o poder da cidade de Babilônia ultrapassava em muito o sul da Mesopotâmia e se estendia por uma vasta região do Antigo Oriente Médio. ${ }^{107}$

\footnotetext{
98 SMITH, Ralph L. Teologia do Antigo Testamento: história, método e mensagem. São Paulo: Vida Nova, 2001. p. 180-183.

99 MÜLLER, H. P. קדש. In: JENNI, Ernst; WESTERMANN, Claus (Orgs.). Theological lexicon of the Old Testament. Peabody: Hendrickson, 1997. v. 3. p. 110-111.

100 ABUSCH, T. Marduk. In: TOORN, K. van der, BECKING, P., HORST, P. W. van der. Dictionary of Deities and Demons in the Bible. Leiden: Brill, 1999. p. 542.

101 LEICK, 2003, p. 53.

102 CHILDS, 2001, p. 366; SMITH, 2009, p. 303. Ver seção “Análise Literária de Isaías 47".

103 WESTERMANN, 1969, p. 191.

104 CROATTO, 1994, p. 163.

105 SMITH, 2009, p. 303; RIDDERBOS, 1995, p. 384.

106 CROATTO, 1994, p. 163.

107 GROGAN, 1992, p. 277.
} 
O versículo 6 começa com um paralelismo sinônimo direto, ${ }^{108}$ em que o sentido da mensagem é realçado e intensificado à medida que se avança na leitura do texto. ${ }^{109} \mathrm{O}$ "enfurecer-se" de Yahweh o leva a "profanar" seu "povo", que recebe uma descrição mais comovente na segunda linha, "minha herança", uma expressão extremamente significativa para o contexto israelita, pois a "herança" estava relacionada à posse inalienável da família (transmitida a cada geração - Dt 19.14) e à porção prometida e dada por Yahweh na Terra da Promessa (cf. Gn 15.7-8, 18-21) - uma realidade distante para o povo do Exílio. Ao "profanar" a "herança", Isaías quer comunicar a profunda dor sentida por Yahweh e sua ação drástica ao submeter seu povo ao cativeiro.

Da perspectiva do profeta, Babilônia só foi capaz de conquistar Jerusalém porque o Deus de Israel entregou seu povo nas mãos dela (v. 6). "Esse é o motivo pelo qual os judeus foram deportados - não porque Babilônia era agressiva e autônoma nem porque Yahweh amava Nabucodonosor, mas porque Babilônia era um instrumento útil e disponível para o furor de Yahweh". ${ }^{110}$

A “senhora dos reinos" não recebe a sentença por dominar Judá, mas porque "não lhe ofereceste compaixão" (v. 6). ${ }^{111}$ Essa atitude compassiva não foi demonstrada sequer aos "velhos". "A crueldade para com mulheres, pequenas crianças inocentes e idosos em tempo de guerra era um barômetro da ética de qualquer nação poderosa". ${ }^{112}$

Ao final da segunda parte, no versículo 7, os pensamentos de Babilônia são expostos. O cerne da arrogância desse império estava na pressuposição de que seu reino seria eterno; afinal de contas, Babilônia havia derrotado a Assíria - que dominara o Antigo Oriente Próximo por séculos - e, aparentemente, não havia nenhum poder páreo para a força política e militar que os caldeus agora dispunham. ${ }^{113}$ Por trás desse desejo da "cidade" está a pretensão do próprio "imperador". "A cidade é o símbolo do poder político, militar e econômico, concentrado efetivamente no rei, do qual não se fala para por em primeiro plano o estrutural e permanente, em vez de uma figura histórica fugaz". 114

Aqui, o autor apresenta a razão para a conduta externa de Babilônia descrita no versículo 6, bem como a lembrança de que tal postura tem consequências, embora ignoradas pela rainha. Há uma ligação clara entre ação externa ("não lhes ofereceste compaixão" - v. 6) e a ausência de uma reflexão interna ("não consideraste essas coisas em

108 RYKEN, 1992, p. 181; CHISHOLM JR., Robert B. From exegesis to exposition: a practical guide to using biblical hebrew, posição 1709-1711. Edição Kindle.

109 KÖSTENBERGER, Andreas; PATTERSON, Richard. Convite à interpretação bíblica: fundamentos da tríade hermenêutica - história, literatura e teologia. São Paulo: Vida Nova, 2014. p. 240.

110 BRUEGGEMANN, 1998, p. 95.

111 CHILDS, 2001, p. 366.

112 SMITH, 2009, p. 303.

113 CONSTABLE, Thomas L. Notes on Isaiah. Disponível em: <http://www.soniclight.com>. Acessado em: maio 2016. p. 222.

114 CROATTO, 1994, p. 165. 
teu coração" - v. 7) - que impediria a barbárie - desenvolvida na construção do verbo לא o advérbio. Tal construção sintática ocorre exatamente da mesma forma nos dois versículos consecutivos ("não ofereceste [...] não consideraste..."). O tratamento áspero contra Judá expressava um coração arrogante que não ponderou nas consequências daquela atitude.

Quando "essas coisas" progridem para o "fim delas" (v. 7), 115 o autor ressalta o "fim" que aquela postura poderia enfrentar, o fato de que a própria Babilônia seria vítima dos mesmos maus tratos, caso a situação se revertesse futuramente e ela fosse subjugada por outra nação.

Pois bem, ouve isto... (47.8-11)

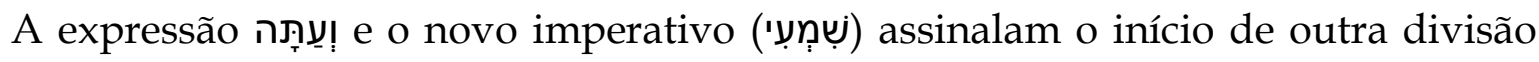
do capítulo (v. 8). ${ }^{116}$ Chama a atenção a reivindicação íntima de Babilônia: "Eu sou, e não há ninguém além de mim", que é feita apenas por Yahweh em outras passagens da segunda parte de Isaías $(45.5,6,18,21-22$; 46.9; cf. 43.11). Isso revela a falsa pretensão e arrogância de Babilônia!117 Uma reivindicação semelhante havia sido feita por Nínive (Sf 2.15), devastada em 612 a.C., e implica a crença em um poder terreno absoluto.118 "Ao se apropriar desses atributos, Babilônia e toda iniciativa humana como a dela se colocam em um curso de colisão com Deus". 119

A rainha orgulhosa afirma, com toda convicção, que não ficará viúva nem perderá seus filhos (v. 8), os piores desastres que poderiam ocorrer a uma mulher no Antigo Oriente Próximo, ${ }^{120}$ pois, nessas condições, ela perdia seu poder econômico e terminava em escravidão. ${ }^{121}$ No entanto, o oposto de seu pensamento ocorre: em um único dia, ela ficará viúva e sem filhos (v. 9); logo os impostos de seus cidadãos e os tributos das nações vassalas passariam para outro rei. ${ }^{122}$ "Assim como ela passa da autoridade para a servidão, ela passará da segurança da vida de esposa e da alegria da maternidade para a insegurança da viuvez e para a solidão da perda" de filhos. ${ }^{123}$

Na Babilônia, a intelectualidade e a magia se combinavam, e o homem sábio era instruído em todas as artes relacionadas ao sobrenatural (cf., e.g., Dn 2.1-13); isso gerava certa complacência no povo e nas autoridades, pois criam que seus magos poderiam

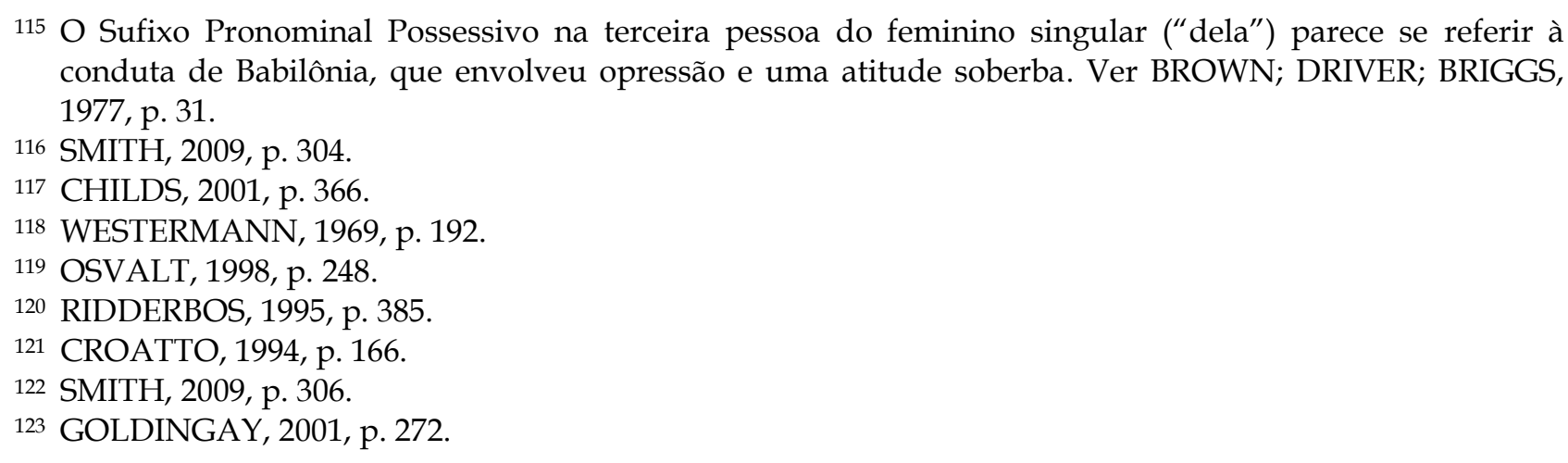


prever a chegada de um inimigo e o modo de derrotá-lo. ${ }^{124}$ No entanto, toda a magia e os encantamentos não teriam efetividade alguma diante da decisão de Yahweh de deixar Babilônia viúva e sem filhos (v. 9). Como afirmou Brueggemann:

\begin{abstract}
Se Yahweh não é reconhecido, então Yahweh vem como o Grande Devastador. Nada poderá impedir o dano, nem a religião babilônica nem a tecnologia babilônica nem o conhecimento babilônico. As reivindicações ideológicas e recursos teológicos do império são totalmente ineficientes. Eles não serão mais capazes de evitar o dano do que os antigos "magos" egípcios ao tentar repelir Yahweh (Êx 8.18; ver Is 19.11-15). O império autoiludido mostra-se completamente impotente e indefeso diante de Yahweh. ${ }^{125}$
\end{abstract}

Nos versículos finais (v. 10 e 11), existe certa ironia na falsa confiança de Babilônia. Como observado na análise literária, ela pensa que "ninguém está me vendo" (אֵין ראִָני) ao

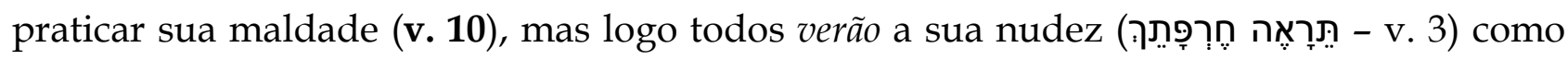
parte do julgamento de Yahweh.

Há também uma ênfase no aspecto do conhecimento que chama a atenção do leitor. O texto nos informa que o império confiou em seu "entendimento" (İ), achando que ele manteria sua hegemonia sobre os outros povos ("Eu [sou], e não há ninguém além [de mim]" - v. 10). No entanto, quando a calamidade vier, Babilônia não "saberá" ('תֵדְעי [mesma raiz que o substantivo] - 2x) esconjurá-la ou prevê-la (v. 11). ${ }^{126}$

Outro jogo de palavras significativo ocorre com o termo רָעָ ("maldade", "impiedade"; "desgraça", "ruína"). Babilônia pratica e confia em sua

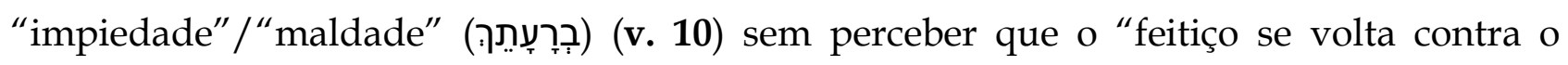
feiticeiro", pois a "calamidade"/ "desgraça" (רָעָ) virá sobre ela de forma imprevisível e inevitável (v. 11).

A alegação de Babilônia no versículo 10 parece superar a concepção de um panteão de deuses e reivindicar ao império e ao rei poder e sabedoria exclusivos, algo que só Yahweh ousa fazer. ${ }^{127}$

Fazendo uso da justiça poética, o profeta menciona ideias relacionadas a "saber", "maldade" e "palavras mágicas" para mostrar que o castigo de Yahweh é proporcional à maldade de Babilônia (v. 11). ${ }^{128}$ "Ela sofrerá um desastre que não será capaz de esconjurar,

\footnotetext{
124 GROGAN, 1992, p. 277; SMITH, 2009, p. 306.

125 BRUEGGEMANN, 1998, p. 95.

126 Ver FRANKE, 1991, p. 413.

127 CROATTO, 1994, p. 167.

128 Para uma explicação e aplicação da justiça poética na profecia hebraica, ver JOHNSTON, 2001a, p. 415436; JOHNSTON, Gordon H. Nahum's rethorical allusions to the neo-Assyrian lion motif. Bibliotheca Sacra, v. 158, 2001b. p. 287-307.
} 
uma calamidade que não será capaz de afastar pagando um resgate, e a súbita catástrofe da qual não havia sido informada por suas artes mágicas". ${ }^{129}$

\section{Referências}

ABUSCH, T. Marduk. In: TOORN, K. van der, BECKING, P., HORST, P. W. van der. Dictionary of Deities and Demons in the Bible. Leiden: Brill, 1999.

ALBERTZ, Rainer. Darius in place of Cyrus: the first edition of Deutero-Isaiah (Isaiah 40.152.12) in 521 BCE. Journal for the Study of the Old Testament, v. 27, n. 3, 2003.

ALONSO SCHÖKEL, Luis. Dicionário bíblico hebraico-português. São Paulo: Paulus, 1997. Unesp, 1997.

. Isaías. In: ALTER, Robert; KERMODE, Frank. Guia Literário da Bíblia. São Paulo:

ASHDOWN, Shelley. A cognitive semantic approach to Redeemer (Go' el) in DeuteroIsaiah. Acta Theologica. v. 35, n. 1, 2015.

BALDWIN, Joyce G. 1 e 2 Samuel: introdução e comentário. São Paulo: Vida Nova, 1996.

BECKING, Bob. Ezra's re-enactment of the exile. In: GRABBE, Lester L. (Org.). Leading captivity captive: 'the exile' as history and ideology. Sheffield: Sheffield Academic, 1998.

BRIGHT, John. História de Israel. 7. ed. São Paulo: Paulus, 2003. p. 425; CALVIN, John. Commentary on the prophet Isaiah. Albany: AGES, 1998. v. 2.

BROWN, F.; DRIVER, S.; BRIGGS, C. The Brown-Driver-Briggs Hebrew and English lexicon. Oxford: Clarendon, 1977.

BRUEGGEMANN, Walter. Isaiah 40-66. Louisville: Westminster John Knox, 1998.

BYARGEON, Rick. Thus saith the Lord: interpreting the prophetic word. In: CORLEY, Bruce; LEMKE, Steve W.; LOVEJOY, Grant I. Biblical hermeneutics: a comprehensive introduction to interpreting Scripture. 2. ed. Nashvile: Broadman \& Holman, 2002.

CHILDS, Brevard S. Isaiah. Louisville: Westminster John Knox, 2001.

CHISHOLM JR., Robert B. From exegesis to exposition: a practical guide to using biblical hebrew, posição 1709-1711. Edição Kindle.

. Uma teologia de Isaías. In: ZUCK, Roy B. Teologia do Antigo Testamento. Rio de Janeiro: CPAD, 2009.

CONSTABLE, Thomas L. Notes on Isaiah. Disponível em: <http://www.soniclight.com>. Acessado em: maio 2016.

${ }^{129}$ RIDDERBOS, 1995, p. 386. 
CROATTO, J. Severino. Isaías: la palabra profética y su relectura hermenêutica. Buenos Aires: LUMEN, 1994.

FRANKE, Chris A. The function of the satiric lament over Babylon in Second Isaiah (XLVII). Vetus Testamentum, v. 41, n. 4, 1991.

GESENIUS, F. W. Gesenius' Hebrew and Chaldee lexicon to the Old Testament Scriptures. Bellingham: Logos Bible Software, 2003.

GOLDINGAY, John. Isaiah. Peabody: Hendrickson, 2001.

GORDON, Robert P. 1 \& 2 Samuel: a commentary. Grand Rapids: Zondervan, 1988.

GROGAN, Geoffrey W. Isaiah. In: GAEBELEIN, Frank E. (Org.). The expositor's Bible commentary. Grand Rapids: Zondervan, 1992. v. 6.

HARTLEY, John E. צָבָָ. In: HARRIS, Laird R.; ARCHER JR., Gleason L.; WALTKE, Bruce K. Dicionário internacional de teologia do Antigo Testamento. São Paulo: Vida Nova, 1998.

HOLLADAY, W. L.; KÖHLER, L. A concise Hebrew and Aramaic lexicon of the Old Testament. Leiden: Brill, 2000.

JOHNSTON, Gordon H. Nahum's rethorical allusions to neo-Assyrian treaty curses. Bibliotheca Sacra, v. 158, 2001a.

$158,2001 b$

. Nahum's rethorical allusions to the neo-Assyrian lion motif. Bibliotheca Sacra, v.

KEIL, C. F.; DELITZSCH, F. Biblical commentary on the books of Samuel. Edinburgh: T \& T Clark, 1880.

KIRST, Nelson, et al. Dicionário hebraico-português e aramaico-português. São Leopoldo: Sinodal, 1987.

KÖSTENBERGER, Andreas; PATTERSON, Richard. Convite à interpretação bíblica: fundamentos da tríade hermenêutica - história, literatura e teologia. São Paulo: Vida Nova, 2014.

LACK, R. La symbolique du livre d'Isaïe. Analecta Biblica. Roma: PIB, 1973.

LEICK, Gwendolyn. A dictionary of Ancient Near Eastern Mythology. New York: Routledge, 2003.

LIPSCHITS, Oded. Demographic changes in Judah between the seventh and the fifth centuries BCE. In: LIPSCHITS, Oded; BLENKINSOPP, Joseph. Judah and the Judeans in the Neo-Babylonian period. Winona Lake: Eisenbrauns, 2003.

LONGMAN III, Tremper; DILLARD, Raymond B. Introdução ao Antigo Testamento. São Paulo: Vida Nova, 2006. 
MACK, Eduard. God, names of. In: ORR, James (Org.). The international Standard Bible encyclopedia. Grand Rapids: Eerdmans, 1939. Edição eletrônica.

MACKENZIE, Donald A. Myths of Babylonia and Assyria. London: The Gresham, 1915.

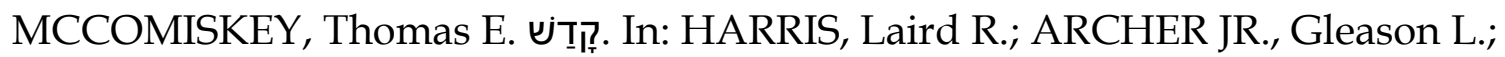

WALTKE, Bruce K. Dicionário internacional de teologia do Antigo Testamento. São Paulo: Vida Nova, 1998.

MERRILL, Eugene H. História de Israel no Antigo Testamento. Rio de Janeiro: CPAD, 2001.

MÜLLER, H. P. קדש. In: JENNI, Ernst; WESTERMANN, Claus (Orgs.). Theological lexicon of the Old Testament. Peabody: Hendrickson, 1997. v. 3.

MYERS, A. C. (Org.). The Eerdmans Bible dictionary. Grand Rapids: Eerdmans, 1987.

OSVALT, John N. The book of Isaiah: chapters 40-66. Grand Rapids: Eerdmans, 1998. . The holy one of Israel: studies in the book of Isaiah. Eugene: Cascade, 2014.

PEARCE, Laurie. New evidence for Judeans in Babylonia. In: LIPSCHITS, Oded; OEMING, Manfred (Orgs.). Judah and the Judeans in the Persian Period. Winona Lake: Eisenbrauns, 2006.

PINTO, Carlos Osvaldo. Foco e desenvolvimento no Antigo Testamento. São Paulo: Hagnos, 2006.

PLEINS, J. David. The social visions of the Hebrew Bible: a theological introduction. Louisville: Westminster John Knox, 2001.

RIDDERBOS, J. Isaías: introdução e comentário. 2. ed. São Paulo: Vida Nova, 1995.

ROGERS, Robert W. Babylonia and Assyria, religion of. In: ORR, James (Org.). The international Standard Bible encyclopedia. Grand Rapids: Eerdmans, 1939. Edição eletrônica.

ROSS, J. P. Jahweh șebâôt in Samuel and Psalms. Vetus Testamentum, v. 17, n. 1, 1967.

RYKEN, Leland. Words of delight: a literary introduction to the Bible. Grand Rapids: Baker, 1992.

SAUER, G. "נקם". In: JENNI, Ernst; WESTERMANN, Claus (Orgs.). Theological lexicon of the Old Testament. Peabody: Hendrickson, 1997. v. 2.

SMICK, Elmer B. נקם. In: HARRIS, Laird R.; ARCHER JR., Gleason L.; WALTKE, Bruce K. Dicionário internacional de teologia do Antigo Testamento. São Paulo: Vida Nova, 1998.

SMITH, Gary V. Isaiah 1-39. Nashville: Broadman \& Holman, 2007. . Isaiah 40-66. Nashville: Broadman \& Holman, 2009. 
SMITH, Mark. O memorial de Deus: história, memória e a experiência do divino no Antigo Israel. São Paulo: Paulus, 2006.

SMITH, Ralph L. Teologia do Antigo Testamento: história, método e mensagem. São Paulo: Vida Nova, 2001.

SWANSON, J. Dictionary of biblical languages with semantic domains: Hebrew. Oak Harbor: Logos Research Systems, 1997. verbete עִרְוָ (Edição Eletrônica).

VEEN, Peter van der. Sixth-century issues: the fall of Jerusalem, the Exile and the return. In: HESS, Richard S.; ARNOLD, Bill T. (Orgs.). Ancient Israel's history: an introduction to issues and sources. Grand Rapids: Baker, 2014.

VITÓRIO, Jaldemir. Proclamar la esperanza en medio del fracaso: teologia bíblica del exílio. Christus, v. 69, n. 747, 2005.

VON RAD, Gerhard. Teologia do Antigo Testamento. 2. ed. São Paulo: ASTE, 2006.

WALTKE, Bruce K.; O'CONNOR, M. Introdução à sintaxe do hebraico bíblico. São Paulo: Cultura Cristã, 2006.

WANKE, G. עָפָר. In: JENNI, Ernst; WESTERMANN, Claus (Orgs.). Theological lexicon of the Old Testament. Peabody: Hendrickson, 1997. v. 2.

WESTERMANN, Claus. Handbook to the Old Testament. Minneapolis: Augsburg, 1967. . Isaiah 40-66: a commentary. Philadelphia: Westminster, 1969.

WISEMAN, D. J. Babylonia. In: MARSHALL, I. H. et al. (Orgs.). New Bible dictionary. 3. ed. Downers Grove: InterVarsity, 1996. 